\title{
Rituximab: the Lupus Journey
}

\section{Lucía Ramos, $M D^{1}$ \\ David Isenberg, MD FRCP ${ }^{2, *}$}

\author{
Address \\ ${ }^{1}$ Internal Medicine Department, Complejo Hospitalario Universitario A Coruña, \\ A Coruña, Spain \\ ${ }^{*}, 2$ Centre for Rheumatology, Department of Medicine, University College London, \\ Room 424, The Rayne Building, 5 University Street, London, WC1E 6JF, UK \\ Email: d.isenberg@ucl.ac.uk
}

Published online: 6 January 2015

(C) Springer International Publishing AG 2015

This article is part of the Topical Collection on Lupus

Keywords Systemic lupus erythematosus - SLE - Lupus nephritis - Rituximab therapy - B cell depletion

\section{Opinion statement}

Since the 1950s, lupus has changed from being a life-threatening condition to being treatable in most cases thanks to the introduction of steroids, immunosuppressive drugs, dialysis and renal transplantation. However, apart from the introduction of mycophenolate mofetil, successful new drugs for lupus have been hard to find in the past two decades. In an assessment of our lupus nephritis cohort over the past 30 years (Croca et al., Rheumatology. 11; 50:1424-1430), we reported that both morbidity and mortality have changed little during this period, suggesting that we have optimized the use of corticosteroids and conventional immunosuppressive drugs. If we want to seek further improvement in outcome, new approaches will be necessary. In this review, we will focus on the use of rituximab in the treatment of systemic lupus erythematosus (SLE). Although not fully understood, it has become clear that B cells play a key role in SLE pathogenesis. They are implicated in the production of autoantibodies, presentation of autoantigen to $T$ cells, T cell activation and cytokine production. In theory, B cell-targeted therapies which eliminate pathogenic $B$ cells and promote the expansion and function of protective $B$ cells, or both, should be beneficial (Rahman and Isenberg, N Engl J Med. 2008; 358:929-39), (Yildirim-Toruner and Diamond, J Allergy Clin Immunol. 2011; 127:303-12). Many openlabel and registry studies do indeed report the successful use of rituximab in both renal and non-renal lupus. However, two major clinical trials using it failed to meet their end points. We review the road travelled by rituximab as a lupus treatment in the past 14 years and consider where the journey is heading.

\section{Key Messages}

- Rituximab is a safe and effective treatment for refractory SLE patients.

- Early treatment with Rituximab seems to be effective and can reduce steroid burden. 


\section{Introduction}

Rituximab is a chimeric mouse/human monoclonal antibody against the B cell-specific antigen CD20, which depletes B cells from peripheral blood. Initially, it was approved in 1997, for the treatment of relapsed or refractory non-Hodgkin's lymphoma [2, 3]. Most observers in the 1990s seemed to believe that rheumatoid arthritis (RA) was principally caused by abnormalities of $\mathrm{T}$ cell function and cytokine excess. In contrast, Professor Jo Edwards and Dr. Geraldine Cambridge, based at the University College London, did not. They became convinced that the role of the $\mathrm{B}$ lymphocyte in rheumatoid arthritis was not fully appreciated, and, based on this belief, they took the view that anything that could dampen down B cell activity would be a useful therapeutic approach. Professor Edwards tried to get access to this drug to use in rheumatoid arthritis from Roche, who manufactures it, on several occasions. It was not until the fourth time of asking that the company gave him a sufficient quantity, initially to treat five patients, all of whom responded very well with ACR50 or 70 responses. These first rheumatoid arthritis patients were treated in 1999.

Supporting the same theory, one of us (DAI) felt that if rituximab was going to work for rheumatoid arthritis, where the data that $\mathrm{B}$ cells were a major pathogenetic factor was less compelling than with lupus, clearly this drug ought to be given to patients with systemic lupus erythematosus (SLE). After a face-to-face interview with the Use of Medicines Committee at University College Hospital (UCH), he was granted permission, in 2000, to treat patients with lupus who had failed conventional immunosuppressive therapy. This was the first open, uncontrolled study of rituximab for patients with SLE. Thus began an odyssey that this review reflects, highlighting both the high points of the journey and its bleaker moments.

\section{Open-Label Studies}

The off-label use of rituximab was first reported in 2002, at UCH by Leandro et al. [4], and since then, it has been increasingly used in patients with SLE. Following this initial attempt, many open-label studies have been published trying to show the efficacy of rituximab in the treatment of patients with SLE with active, renal or non-renal, disease poorly controlled despite standard immunosuppressive treatment used for sufficient time at optimal doses [5-10].

Casals et al. [11] reviewed the evidence of the therapeutic use of rituximab in 188 adults with active, multi-organ SLE (with three or more clinical features) refractory to corticosteroid and immunosuppressive drugs. They reported a clinical response in $171(91 \%)$ of the patients treated with rituximab. Two rituximab regimens that were always administrated with steroids to minimize allergic responses [27] were used. One regime that is recommended for the treatment of lymphoma prescribes $375 \mathrm{mg} / \mathrm{m}^{2}$ of rituximab weekly for 4 weeks and the other uses two 1000-mg doses separated by 15 days. They reported a higher rate of therapeutic response in patients treated with four weekly doses ( 94 vs $83 \%, p=0.048$ ). This finding suggests that some cases may require higher doses of rituximab to achieve a clinical response for induction therapy.

Given that renal disease occurs in 30-60 \% of all patients with SLE at some time during the disease, major efforts have been made to prove the efficacy of rituximab in the last decade [9]. Casals et al. [11] also analyzed lupus nephritis (LN) patients in their systematic review. They described 106 biopsy-proven LN patients who had been treated with rituximab. In 52 (49\%) cases, rituximab was administered for LN refractory to standard therapies, in 37 (35\%) for LN flare and in 17 (16\%) as first-line therapy. A favourable therapeutic response (partial or complete response; for definitions, see Table 1) was achieved in 73 
(69 \%) patients, 8 (80 \%) in type III LN patients, 26 (67\%) in type IV, 4 (57\%) in type $\mathrm{V}$ and $18(78 \%)$ in mixed membranous-proliferative LN. In conclusion, they found a global efficacy of $70 \%$, with half the patients each having a complete and partial response.

The LESIMAB study, a multicentre longitudinal study, has provided new data showing that rituximab can result in a high response rate in patients with refractory SLE after 10 weeks following its infusion [12]. One hundred twenty eight patients with refractory lupus were treated with at least one infusion of rituximab, 63 of them had lupus nephritis (55 patients with kidney biopsy). Seventy eight percent of the patients achieved a response rate at the end of the study (see Table 1) with a mean time of 3 to 4 months, accompanied by a notable decrease in steroid requirement. The patients were relapse free for a mean of 10.8 months. Only $38 \%$ of responders experienced a flare (mostly mild) after the final rituximab infusion. They did not compare directly both doses of infusion, but they found that the regimen of four doses of rituximab was associated with a fivefold elevated risk of serious infection compared to two doses.

Gregersen and Jayne discussed the evidence derived from clinical trials and case studies in the period between 2004 and 2012 in a systematic review (in total, 300 patients were included in 21 studies with a follow-up period ranged from 3 months to over 36 months) [13]. They confirmed that the most frequent indication for rituximab therapy was refractory or relapsing lupus nephritis, the time to remission being longer than 6 months, with partial remission in less than 6 months; proliferative lupus nephritis was the most common histological diagnosis $(75 \%)$. They also observed that patients with class III lupus nephritis had greater improvement with rituximab than patients with class IV or V lupus nephritis. As other investigators have observed, they found that, as expected, rituximab seemed to have decreased efficacy in individuals with renal failure. Thus, eGFR $<60 \mathrm{ml} / \mathrm{min} / 1.73 \mathrm{~m}^{2}$ and nephrotic syndrome were features predictive of a poor prognosis in patients $[14,15]$. Patients with nephrotic syndrome may excrete rituximab more rapidly, along with albumin and immunoglobulins. If this possibility is a concern, it might be appropriate to give more frequent doses of rituximab $[16,17]$.

Another long-term follow-up study of 25 LN patients, treated with a combination of rituximab, cyclosporine and glucocorticoids [7], showed that renal response following treatment mainly occurred after a median time of 12 months in 22 patients, 16 of them achieved complete response after 2 years of follow-up, proving a significant improvement in renal biopsies as well. Furthermore, only six renal flares were observed in those patients, a low rate, taking into account that the patients included had relapsing disease at inclusion. The fact that they observed a transition from partial to complete response during the second year of follow-up indicates that clinical trials in LN need longer follow-up.

Finally, an open-labelled clinical study of 18 lupus nephritis patients suggested that the combination of rituximab and low-dose intravenous cyclophosphamide can be an effective and well-tolerated therapeutic option for refractory LN with an overall response rate of $72 \%$ at 6 months $[9,18]$. 


\section{Table 1. Definition of complete and partial lupus nephritis response in the different studies}

\begin{tabular}{|c|c|c|}
\hline & Complete response (CR) & Partial response (PR) \\
\hline Casals et al. [11] & $\begin{array}{l}\text { Normal serum creatinine and serum albumin } \\
\text { levels, inactive urinary sediment and } 24-\mathrm{h} \\
\text { urinary albumin }<0.5 \mathrm{~g} \text {. Some studies also } \\
\text { applied the ACR response } \\
\text { criteria for proliferative and membranous renal } \\
\text { disease in SLE clinical trials [45] or the Systemic } \\
\text { Lupus International Collaborating Clinics Renal } \\
\text { Activity/Response indexes [46] }\end{array}$ & $\begin{array}{l}>50 \% \text { improvement in all renal parameters } \\
\text { that were abnormal at baseline, which has } \\
\text { no deterioration in any parameter, except in } \\
\text { one study in which they used a }>40 \% \\
\text { improvement }\end{array}$ \\
\hline $\begin{array}{l}\text { The LESIMAB } \\
\text { study [12] }\end{array}$ & $\begin{array}{l}\text { Safety of Estrogens in Lupus Erythematosus } \\
\text { National Assessment-Systemic Lupus } \\
\text { Erythematosus Disease Activity Index (SELENA- } \\
\text { SLEDAI) score of two points or less and a } \\
\text { modified SELENA-SLEDAI Flare Index (SFI) } \\
\text { score of zero }\end{array}$ & $\begin{array}{l}\text { Reduction or at least four points in SELENA- } \\
\text { SLEDAI score with no new or worsening } \\
\text { symptoms as measured by the SELENA- } \\
\text { SLEDAI-SFI }\end{array}$ \\
\hline $\begin{array}{l}\text { Gregersen and } \\
\text { Jayne [13] }\end{array}$ & $\begin{array}{l}\text { Decreased proteinuria, improved kidney function } \\
\text { and decreased expression of serological } \\
\text { markers of disease activity, in parallel } \\
\text { with improved clinical measures }\end{array}$ & \\
\hline Jónsdóttir et al. [7] & LN European consensus Statement [47] & \\
\hline Davies et al. [9] & $\begin{array}{l}\text { Normal serum creatinine and serum albumin } \\
\text { levels, inactive urine sediment and proteinuria } \\
<0.5 \mathrm{~g} / \text { day }\end{array}$ & $\begin{array}{l}50 \% \text { improvement in all renal parameters that } \\
\text { were abnormal at baseline }\end{array}$ \\
\hline $\begin{array}{l}\text { Gunnarsson et al. } \\
\text { [18] }\end{array}$ & $\begin{array}{l}\text { Proteinuria }<0.5 \mathrm{~g} / \text { day, combined with } \\
\text { normalization or improvement of serum } \\
\text { creatinine and other nephritis-related variables }\end{array}$ & $50 \%$ reduction in renal findings \\
\hline $\begin{array}{l}\text { UK-BIOGEAS } \\
\text { registry [19] }\end{array}$ & $\begin{array}{l}\text { Normal serum creatinine with inactive urinary } \\
\text { sediment and } 24-\mathrm{h} \text { urinary albumin }<0.5 \mathrm{~g}\end{array}$ & $\begin{array}{l}>50 \% \text { improvement in all renal parameters } \\
\text { that were abnormal at baseline, with no } \\
\text { deterioration in any parameter }\end{array}$ \\
\hline AIR registry [20] & $\begin{array}{l}\text { Decrease in proteinuria to }<0.5 \mathrm{~g} / \text { day, } \\
\text { disappearance of hematuria and normalization } \\
\text { of estimated glomerular filtration rate }\end{array}$ & $\begin{array}{l}\geq 50 \% \text { improvement in all renal parameters } \\
\text { (serum creatinine level and proteinuria) } \\
\text { with abnormal values at baseline }\end{array}$ \\
\hline GRAID registry [21] & $\begin{array}{l}\text { SELENA-SLEDAI score of } \leq 2 \text { with a SELENA- } \\
\text { SLEDAI flare index of zero }\end{array}$ & $\begin{array}{l}\text { Reduction in the SELENA-SLEDAI score of } \geq 4 \\
\text { with no new or worsening of symptoms }\end{array}$ \\
\hline
\end{tabular}

\section{Registry Data}

Several registries have been established trying to reflect the use of rituximab in actual clinical practice. The UK-BIOGEAS Registry pooled data from European cohorts of 164 patients with biopsy-proven lupus nephritis refractory patients [19]. In $82(50 \%)$ cases, rituximab was administered for LN refractory to standard therapies, in 69 (42\%) for LN flare and in 13 (8\%) as first-line therapy. The renal biopsy data showed type IV LN in 93 (57\%) patients, type III in $26(16 \%)$, type V in 20 (12\%), type II in $6(4 \%)$ and mixed-membranous 
LN with proliferative lesions in 19 (12\%). Response rates were assessed at 6 months in 110 patients. They found a favourable clinical response in $67 \%$ of patients at both 6 and 12 months with a rate of complete response of $27 \%$ at 6 months and $30 \%$ at 12 months (see Table 1). The remaining 42 (33\%) were classified as non-responders. Furthermore, a different rate of response was found in accordance with the ISN/RPS histopathological classification, with a fourfold higher rate of CR at 12 months in patients with proliferativemembranous LN (70 \%) in comparison with those with type IV LN (22\%).

The French AutoImmunity and Rituximab Registry (AIR) analyzed the efficacy of rituximab treatment in 136 lupus patients [20]. One hundred thirteen patients with at least 3 months follow-up visit (not sure what this means, at least one 3-month follow-up?) were assessed. An overall response was observed in $87(77 \%)$ and a corticosteroid-sparing effect noted. The response to rituximab overall did not differ significantly between patients receiving rituximab monotherapy and those given concomitant immunosuppressive agents, but tended to be higher in those receiving rituximab monotherapy ( 84 vs $70 \%, p=$ 0.08 ). Thirty one of the 36 responders who were followed up for more than 6 months (41\%) experienced a relapse $14.9 \pm 7.6$ months after the last rituximab infusion. Although the relapse rate was similar, relapses occurred earlier in patients not taking immunosuppressive agents than in those taking them. Twenty five of the 31 relapsed patients received retreatment with rituximab. After retreatment, a response was noted in 20 of 22 (91\%) patients (no available data from the other three patients). Four patients received regular retreatment with rituximab as maintenance therapy every 6 months, and two others after a first relapse episode. These patients did not relapse during maintenance therapy after a mean follow-up of 22 months.

The German Registry of Autoimmune Diseases (GRAID) [21] analyzed 85 lupus patients in whom rituximab was used because of inefficacy with conventional treatment in 71 (89.9\%), side effects in 25 (31.6\%) and/or contraindications in $11(13.9 \%)$ patients. They observed a complete treatment response in $37(46.8 \%)$ of patients, a partial response in 27 (34.2\%) (see Table 1) and 15 (19\%) patients did not respond.

In spite of these encouraging data, rituximab failed to meet its primary or secondary end points in two randomized controlled trials comparing the addition to rituximab or placebo to standard of care in extra-renal lupus (EXPLORER) [22] and in lupus nephritis (LUNAR) [23•]. There are a number of possible explanations for these results, including differences in the types of patients recruited in terms of disease activity, background immunosuppressives, use of active comparator drug, rituximab dosing regimen, very high doses of concomitant steroids, steroid tapering, adverse events, follow-up period, nonpowered sample size and inability of disease activity instruments to capture response. Conversely, it is true that responses in open-label studies may be difficult to interpret due to variable doses and use of concomitant drugs, observer bias, uncontrolled use of steroids and other treatments and regression

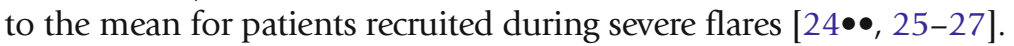

However, post hoc LUNAR trial analysis, as well as other systematic reviews, has supported the view that rituximab is effective in inducing partial and, to a 
lesser extent, complete remission of lupus nephritis [16, 28].

In a post hoc analysis, the LUNAR trial showed a trend toward the benefit in African-American and Hispanic patients with lupus nephritis [29]. Few studies report data on ethnicity in lupus patients treated with rituximab. However, in some, black ethnicity has been associated with failure to achieve B cell depletion and, consequently, with the absence of remission or non-response [13, 30-32].

\section{Biomarkers}

Efforts have been made to find biologic response markers of use in patients given rituximab [33]. The aim in depleting B cell lymphocytes is to diminish their differentiation into plasma cells and, therefore, decrease the production of autoantibodies. Specific B cell depletion therapy with rituximab improves peripheral B cell abnormalities in SLE patients and it is associated with a reduction in anti-dsDNA, anticardiolipin and antinucleosome antibody levels, but no change is seen in anti-Ro, anti-La, anti-Sm or anti-RNP antibodies [34]. These findings indicate that anti-ENA antibodies are secreted by long-lived plasma cells, whereas anti-DNA/nucleosome/anticardiolipin antibodies are coming, at least in a proportion of patients, from short-lived plasma cells.

Vital et al. [24••] studied the effects on B cell depletion in detail. B cells were shown to predict patterns of response and relapse. They measured the peripheral blood B cells in 39 rituximab-treated SLE patients. To do this, they used a highly sensitive flow cytometry (HSFC) technique which can enumerate B cells at levels 50-100 times lower than conventional techniques. They reported that an incomplete B cell depletion at 6 weeks was associated with lower clinical response rates at 26 weeks. All patients with complete B cell depletion had major or partial clinical response, and those who did not respond had persistent $\mathrm{B}$ cells after the second infusion of rituximab. The reduction in levels of B cells in peripheral blood occurs within days to weeks and the effect is sustained for up to 6 months on average, although earlier depletion is relatively common and rarely it can be much longer. We have a patient treated with rituximab (1 g twice) in 2001 who remains B cell depleted 13 years later (unpublished observation). Complete deletion of circulating $B$ cells increases the likelihood of a clinical response. Inevitably, relapses do not become apparent until repopulation of memory B cells and plasmablasts occurs. Indeed, the timing of relapses can be predicted with reasonable accuracy by the levels of the cells at repopulation. Even in the EXPLORER and LUNAR trials, B cell-depleting therapy was associated with statistically significant improvement in the serological markers of disease activity, namely a reduction in the anti-dsDNA antibody levels and an increase in C3 levels.

Broadly speaking, the degree of B cell depletion accords with the overall response to rituximab treatment. Thus, the effectiveness of the $\mathrm{B}$ cell depletion correlates with better clinical outcome. Failure to achieve adequate depletion is often linked to poor clinical outcome. However, the correlation is not absolute since complete B cell depletion may not bring about clinical remission and an incomplete depletion may still lead to some clinical improvement. As Lazarus et al. [35] demonstrated, patients with SLE respond differently to B cell depletion therapy depending on the duration of $\mathrm{B}$ cell depletion and their levels of anti-dsDNA antibodies. They analyzed 61 refractory SLE patients treated with 


\section{Table 2. Most important UCH findings}

\begin{tabular}{|c|c|}
\hline Leandro et al. [4] & BCDT using rituximab is an effective treatment in SLE patients \\
\hline $\begin{array}{l}\text { Turner-Stokes et al. } \\
\text { [48] }\end{array}$ & $\begin{array}{l}\text { Administration of repeated cycles of rituximab is a safe and effective treatment for active, refractory SLE } \\
\text { Retreatment with rituximab may produce a more sustained clinical response }\end{array}$ \\
\hline Ezeonyeji [41] & $\begin{array}{l}\text { Rituximab is an effective treatment when it is used early in the disease and offers a useful method of } \\
\text { reducing the cumulative steroid burden in patients with predominantly non-renal SLE }\end{array}$ \\
\hline Jónsdóttir [49] & BCDT using rituximab is as effective for proliferative lupus nephritis as for membranous lupus nephritis \\
\hline $\begin{array}{l}\text { Cambridge et al. } \\
{[50]}\end{array}$ & $\begin{array}{l}\text { The BCDT with rituximab was associated with reduction in anti-dsDNA and antinucleosome antibody } \\
\text { levels but not in antihistone, anti-SSA, anti-RNP/Sm (anti-RNP), and anti-Sm antibodies levels }\end{array}$ \\
\hline Lazarus et al. [35] & $\begin{array}{l}\text { SLE patients respond differently to BCDT depending on the duration of B cell depletion, their levels of } \\
\text { anti-dsDNA antibodies and the type of B cells that repopulate }\end{array}$ \\
\hline $\begin{array}{l}\text { Cambridge et al. } \\
\text { [51] }\end{array}$ & Patients anti-ribonucleoprotein (RNP)/Sm positive seem to do less well after BCDT \\
\hline Carter et al. [36] & $\begin{array}{l}\text { BAFF may be particularly influential in SLE disease activity following BCDT and would support the } \\
\text { rationale for using BAFF-targeted therapies following B cell repopulation, particularly in patients who } \\
\text { relapse after BCDT showing high BAFF levels, low B cell numbers and high anti-dsDNA antibody levels }\end{array}$ \\
\hline
\end{tabular}

rituximab. They observed that SLE patients respond differently to B cell depletion depending on its duration, the levels of anti-dsDNA antibodies and the type of B cells that repopulate. They found patients with very low B cell numbers who relapsed with high anti-dsDNA antibody levels, whereas some patients with low anti-dsDNA antibody levels relapsed with similar numbers of B cells found prior to rituximab treatment. In those patients with high anti-dsDNA levels, they tried to identify the B cell subset most likely to be implicated. They found that plasmablasts are the type that dominates the repopulating B cells.

Finally, Carter et al. [36•] determined whether serum B cell activating factor (BAFF) levels correlate with relapse or remission in SLE patients following treatment with rituximab. They monitored the serum BAFF levels of 35 patients for a minimum of 18 months. Ten patients remained in remission for the whole period but 25 experienced a relapse, 22 of them were treated with another course of rituximab. They found that BAFF levels are inversely related to B cell numbers after treatment with rituximab, with peak levels correlating to the nadir B cell numbers. Flare at the lowest B cell counts was associated with the highest serum BAFF levels. High BAFF levels after B cell depletion and repopulation of peripheral $\mathrm{B}$ cells distinguished those patients with relapsing disease from those remaining in remission. Furthermore, a low BAFF 'state' posttreatment appeared to indicate a favourable clinical outcome.

They observed that serum BAFF levels during relapse after B cell depletion were significantly elevated in comparison with those during the disease flare prior to treatment. Serum BAFF levels have been shown to correlate positively with levels of anti-dsDNA antibodies, a correlation that seems to be preserved posttreatment. The observations imply a significant role for BAFF in encouraging disease flare after B cell depletion. Sequential depletion may encourage ever increasing BAFF levels (and rising dsDNA antibody levels) with disease flare occurring even at low B cell numbers. It is tempting to speculate that the use of belimumab (which is an anti-BAFF biologic) may be of value in these patients $[37 \bullet, 38]$. 


\section{Table 3. The most important findings of some aforementioned articles}

\begin{tabular}{|c|c|}
\hline Croca et al. $[1 \bullet \bullet]$ & $\begin{array}{l}\text { - Lupus nephritis-associated mortality and morbidity have not been significantly reduced over a } 30 \text { - } \\
\text { year period } \\
\text { - Improving prognosis for lupus nephritis patients will require a change in the current therapeutic } \\
\text { approach }\end{array}$ \\
\hline Ramos-Casals et al. [11] & $\begin{array}{l}\text { - The use of rituximab in lupus nephritis patients seems to be effective and relatively safe although } \\
\text { more randomized clinical trials are needed to confirm its open-label use }\end{array}$ \\
\hline $\begin{array}{l}\text { Fernández-Nebro et al. } \\
\text { [12] }\end{array}$ & $\begin{array}{l}\text { - Rituximab is an effective choice in selected patients refractory to standard treatment } \\
\text { (antimalarials, corticosteroids and immunosuppressant drugs) }\end{array}$ \\
\hline $\begin{array}{l}\text { Gregersen and Jayne } \\
\text { [13] }\end{array}$ & $\begin{array}{l}\text { - Anti-CD20 B cell depletion treatment seems to be effective and safe, specially the treatment with } \\
\text { rituximab }\end{array}$ \\
\hline Weidenbusch et al. [16] & $\begin{array}{l}\text { - Rituximab is effective in inducing partial and, to a lesser extent, complete remission of lupus } \\
\text { nephritis in patients who are refractory to standard therapy }\end{array}$ \\
\hline $\begin{array}{l}\text { Gunnarsson and } \\
\text { Jonsdottir [18] }\end{array}$ & $\begin{array}{l}\text { - Rituximab treatment may be effective in lupus nephritis patients who do not respond to the } \\
\text { standard therapy }\end{array}$ \\
\hline Díaz-Lagares et al. [19] & $\begin{array}{l}\text { - Rituximab in lupus nephritis currently seems to be good in real life, but ineffective in controlled } \\
\text { trials } \\
\text { - The main baseline features associated with not achieving complete response were nephrotic } \\
\text { syndrome and renal failure }\end{array}$ \\
\hline Terrier et al. [20] & - The use of rituximab in lupus patients is clinically effective and has a satisfactory tolerance profile \\
\hline Witt et al. [21] & $\begin{array}{l}\text { - The off-label use of rituximab in the treatment of refractory lupus patients is common, efficacious } \\
\text { and seems to have a good side effect profile }\end{array}$ \\
\hline Merrill et al. [22] & $\begin{array}{l}\text { - The EXPLORE trial did not demonstrate differences in clinical responses between placebo group } \\
\text { and rituximab group in patients with moderate to severe lupus }\end{array}$ \\
\hline Rovin et al. [23•] & $\begin{array}{l}\text { - The LUNAR study failed to demonstrate the superiority of rituximab added to MMF plus } \\
\text { corticosteroids over MMF plus corticosteroids alone in achieving either combined complete and } \\
\text { partial responses or complete responses alone } \\
\text { - Demonstrated a better response in Black patients }\end{array}$ \\
\hline Pons-Estel [33] & $\begin{array}{l}\text { - Rituximab has demonstrated through daily practice to be an effective and safe treatment for lupus } \\
\text { nephritis }\end{array}$ \\
\hline Condon et al. $[42 \bullet \bullet]$ & $\begin{array}{l}\text { - Oral steroids can be safely avoided in the treatment of lupus nephritis patients without apparent } \\
\text { reduction in efficacy or increase in relapse rates }\end{array}$ \\
\hline
\end{tabular}

\section{Safety}

In terms of side effects, rituximab used in combination with immunosuppressive therapies has raised concerns about increased risks of infection. However, rituximab therapy is well tolerated and has a low rate of side effects. The most frequent adverse effects reported in literature were infections (predominantly mild respiratory and urinary infections due to common microorganisms), infusion reactions (related to the lack of premedication) and hematologic abnormalities (mainly, neutropenia) $[13,15]$. Very few cases $(<10)$ of progressive multifocal leukoencephalopathy (PML) have been reported in individuals with SLE being treated with rituximab in combination with other 
immunosuppressive drugs. However, its attribution exclusively to rituximab is not warranted, as more cases (around 20-30) have been reported in patients with longstanding active SLE (which itself can increase the risk of PML) not given this biologic, who were treated with various standard immunosuppressive treatments as well as corticosteroids [39, 40].

In the last few years, the idea of treating newly diagnosed SLE patients with rituximab has been introduced, partly to help reduce chronic steroid usage. Ezeonyeji and Isenberg [41] described a steroid-sparing regimen in eight newly diagnosed, mainly non-renal, SLE patients given rituximab at diagnosis. They found that rituximab was as effective as the conventional treatment given to controls (three, matched for each rituximab treated patient). This approach also reduced the cumulative steroid burden.

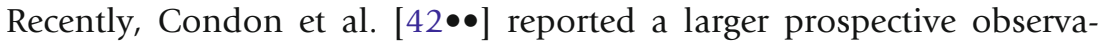
tional single-centre cohort study, in which a rituximab-based therapy, without oral steroids (the rituxilup protocol), was used in 50 biopsyproven active class III, IV or V lupus nephritis patients. At a median time of 37 weeks, $45(90 \%)$ of the patients had achieved partial or complete response (see Table 1). The time to complete or partial response was not influenced by class of LN at baseline. There were 12 relapses in 11 patients (22\%), all nephrotic with a median time to relapse from remission of 65.1 weeks. Of these, eight and four occurred in patients with complete and partial response, respectively. Seven relapses (in six patients) were treated with rituximab, obtaining a complete response is three, a partial response in one and three nonresponders. Only two patients required maintenance steroids because of severe systemic symptoms. In this study, 24 (48\%) patients had negative anti-dsDNA antibodies and $22(44 \%)$ patients had pure class $\mathrm{V}$ lesions at baseline, $18 \%$ of them achieving a complete response at 6 months rising to $36 \%$ by 1 year. This study showed high rates of renal remission, without reduction in efficacy or increase in relapse rates, at least after 3 years of follow-up, and very few required oral steroids $[42 \bullet \bullet, 43,44]$.

\section{Conclusions}

The use of rituximab to treat SLE now goes back 14 years. Our unit at the University College London has made a major contribution to these studies (see Table 2). It seems clear that most physicians who have used it agree that, while it is not a cure for SLE, rituximab can be most effective for virtually all aspects of the disease. The two clinical trials (EXPLORER and LUNAR), which failed, seem likely to have done so because of trial design issues. Although the recent reports of the use of rituximab at the time of diagnosis are most encouraging, full acceptance of the effectiveness of rituximab awaits a successful clinical trial (Table 3). The RITUXILUP study, which aims to compare the use of 
rituximab plus mycophenolate mofetil to steroids plus mycophenolate mofetil in biopsy-proven newly diagnosed renal lupus, may be the necessary catalyst to the widespread acceptance of rituximab in the treatment of patients with SLE.

\section{Compliance with Ethics Guidelines}

\section{Conflict of Interest}

Lucía Ramos declares that he has no conflict of interest.

David Isenberg was a previous consultant for GlaxoSmithKline outside of the submitted work.

\section{Human and Animal Rights and Informed Consent}

Human studies done by authors (but no animal studies).

This article does not contain any studies with animal subjects performed by any of the authors. With regard to the authors' research cited in this paper, all procedures were followed in accordance with the ethical standards of the responsible committee on human experimentation and with the Helsinki Declaration of 1975, as revised in 2000 and 2008.

\section{References and Recommended Reading}

Papers of particular interest, published recently, have been highlighted as:

- Of importance,

$\bullet \quad$ Of major importance

1.• Croca SC, Rodrigues T, Isenberg DA. Assessment of a lupus nephritis cohort over a 30-year period. Rheumatology. 11; 50:1424-1430. This careful study shows the lack of significant improvement in renal outcome by conventional drugs over 30 years.

2. Rahman A, Isenberg DA. Systemic lupus erythematosus. N Engl J Med. 2008;358:929-39.

3. Yildirim-Toruner C, Diamond B. Current and novel therapeutics in the treatment of systemic lupus erythematosus. J Allergy Clin Immunol. 2011;127:303-12.

4. Leandro MJ, Edwards JC, Cambridge G, et al. An open study of B lymphocyte depletion in systemic lupus erythematosus. Arthritis Rheum. 2002;46:2673-7.

5. Pinto LF, Velásquez CJ, Prieto C, et al. Rituximab induces a rapid and sustained remission in Colombian patients with severe and refractory systemic lupus erythematosus. Lupus. 2011;20:1219-26.

6. Hofmann SC, Leandro MJ, Morris SD, Isenberg DA. Effects of rituximab-based B-cell depletion therapy on skin manifestations of lupus erythematosus-report of 17 cases and review of the literature. Lupus. 2013;22:932-9.

7. Jónsdóttir T, Zickert A, Sundelin B, et al. Long-term follow-up in lupus nephritis patients treated with rituximab-clinical and histopathological response. Rheumatology. 2013;52:847-55.

8. Bonilla-Abadía F, Coronel Restrepo N, Tobón GJ, et al. Rituximab for remission induction and maintenance in refractory systemic lupus erythematosus. Autoimmune Dis. 2014.

9. Davies RJ, Sangle SR, Jordan NP, et al. Rituximab in the treatment of resistant lupus nephritis: therapy failure in rapidly progressive crescentic lupus nephritis. Lupus. 2013;22:574-82.

10. Moroni G, Raffiotta F, Trezzi B, et al. Rituximab vs mycophenolate and vs cyclophosphamide pulses for induction therapy of active lupus nephritis: a clinical observational study. Rheumatology (Oxford). 2014.

11. Ramos-Casals M, Diaz-Lagares C, Soto-Cardenas MJ, et al. Rituximab therapy in lupus nephritis: current clinical evidence. Clinic Rev Allergy Immunol. 2011;40:159-69.

12. Fernández-Nebro A, Marenco de la Fuente JL, Carreño L, et al. Multicenter longitudinal study of B-lymphocyte depletion in refractory systemic lupus erythematosus: the LESIMAB study. Lupus. 2012;21:1063-76. 
13. Gregersen JW, Jayne DRW. B-cell depletion in the treatment of lupus nephritis. Nat Rev Nephrol. 2012;8:505-14.

14. Fanouriakis A, Krasoudaki E, Tzanakakis M, Boumpas DT. Recent progress in the treatment of lupus nephritis Mod Rheumatol. 2012;22:803-13.

15. Tesar V, Hruskova Z. Recent news in the treatment of lupus nephritis. Minerva Med. 2012;103:235-51.

16. Weidenbusch M, Römmele C, Schröttle A, Anders HJ. Beyond the LUNAR trial. Efficacy of rituximab in refractory lupus nephritis. Nephrol Dial Transplant. 2013;28:106-11.

17. Chen TK, Fine DM. Top 10 developments in lupus nephritis. Curr Rheumatol Rep. 2013;15:358.

18. Gunnarsson I, Jonsdottir T. Rituximab treatment in lupus nephritis-where do we stand? Lupus. 2013;22:381-9.

19. Díaz-Lagares C, Croca S, Sangle S, et al. Efficacy of rituximab in 164 patients with biopsy-proven lupus nephritis: pooled data from European cohorts. Autoimmun Rev. 2012;11:357-64.

20. Terrier B, Amoura Z, Ravaud P, et al. Safety and efficacy of rituximab in systemic lupus erythematosus. Arthritis Rheum. 2010;62:2458-66.

21. Witt M, Grunkle M, Proft F, et al. Clinical outcomes and safety of rituximab treatment for patients with systemic lupus erythematosus (SLE)-results from a nationwide cohort in Germany (GRAID). Lupus. 2013;22:1142-9.

22. Merrill JT, Neuwelt CM, Wallace DJ, et al. Efficacy and safety of rituximab in moderately-to-severely active systemic lupus erythematosus: the randomized, double-blind, phase II/III systemic lupus erythematosus evaluation of rituximab trial. Arthritis Rheum. 2010;62:222-33.

23. Rovin BH, Furie R, Latinis $\mathrm{K}$, for the LUNAR Investigator Group, et al. Efficacy and safety of rituximab in patients with active proliferative lupus nephritis: the Lupus Nephritis Assessment with Rituximab Study. Arthritis Rheum. 2012;64(4):1215-26.

This study failed to show benefit for rituximab in a major clinical trial, but is flawed by its trial design.

24.•Vital EM, Dass S, Buch MH, Henshaw K, Pease CT, Martin MF, et al. B cell biomarkers of rituximab responses in systemic lupus erythematosus. Arthritis Rheum. 2011;63(10):3038-47. This study shows that more accurate measures of CD19+ B cells optimise the link to clinical response.

25. Reddy V, Jayne D, Close D, Isenberg DA. B-cell depletion in SLE: clinical and trial experience with rituximab and ocrelizumab and implications for study design. Arthritis Res Ther. 2013;15 Suppl 1:S2.

26. Harvey PR, Gordon C. B-cell targeted therapies in systemic lupus erythematosus: successes and challenges. BioDrugs. 2013;27:85-95.

27. van Vollenhoven RF. Challenges and opportunities in SLE clinical trials. Curr Opin Rheumatol. 2013;25:606-15.
28. Touma Z, Urowitz MB, Gladman DD. Systemic lupus erythematosus: an update on current pharmacotherapy and future directions. Expert Opin Biol Ther. 2013;13(5):723-37.

29. Kattah AG, Fervenza FC. Rituximab: emerging treatment strategies of immune-mediated glomerular disease. Expert Rev Clin Immunol. 2012;8(5):413-21.

30. Melander $\mathrm{C}$ et al. Rituximab in severe lupus nephritis: early B-cell depletion affects long-term renal outcome. Clin J Am Soc Nephrol. 2009;4:579-87.

31. Looney RJ et al. B cell depletion as a novel treatment for systemic lupus erythematosus: a phase I/II doseescalation trial of rituximab. Arthritis Rheum. 2004;50:2580-9.

32. Pepper R et al. Rituximab is an effective treatment for lupus nephritis and allows a reduction in maintenance steroids. Nephrol Dial Transplant. 2009;24:3717-23.

33. Pons-Estel GJ, Serrano R, Plasín MA, Espinosa G, Cervera R. Epidemiology and management of refractory lupus nephritis. Autoimmun Rev. 2011;10:65563.

34. Vossenkämper A, Lutalo PMK, Spencer J. Translational mini-review series on B cell subsets in disease. Transitional B cells in systemic lupus erythematosus and Sjögren's syndrome: clinical implications and effects of B cell-targeted therapies. Clin Exp Immunol. 2011;167:7-14.

35. Lazarus MN, Turner-Stokes T, Chavele KM, Isenberg DA, Ehrenstein MR. B-cell numbers and phenotype at clinical relapse following rituximab therapy differ in SLE patients according to anti-dsDNA antibody levels. Rheumatology. 2012;51:1208-15.

36. Carter LM, Isenberg DA, Ehrenstein MR. Elevated serum BAFF levels are associated with rising anti-doublestranded DNA antibody levels and disease flare following B cell depletion therapy in systemic lupus erythematosus. Arthritis Rheum. 2013;65(10):2672-9.

This study suggests that BAFF levels may be useful in predicting flares in SLE post-rituximab.

37. Navarra SV, Guzman RM, Gallacher AE, et al. Efficacy and safety of belimumab in patients with active systemic lupus erythematosus: a randomised, placebocontrolled, phase 3 trial. Lancet. 2011;377:721-31.

The first trial to show the benefit of Benlysta.

38. Furie R, Petri M, Zamani O, et al. A phase III, randomized, placebo-controlled study of belimumab, a monoclonal antibody that inhibits B lymphocyte stimulator, in patients with systemic lupus erythematosus. Arthritis Rheum. 2011;63:3918-30.

39. Harris HE. Progressive multifocal leukoencephalopathy following rituximab in a patient with systemic lupus erythematosus treated with rituximab. Rheumatology (Oxford). 2008;47:224-5.

40. Fleischmann RM. Progressive multifocal leukoencephalopathy following rituximab treatment in a patient with rheumatoid arthritis. Arthritis Rheum. 2009;60:3225-8.

41. Ezeonyeji AN, Isenberg DA. Early treatment with rituximab in newly diagnosed systemic lupus 
erythematosus patients: a steroid-sparing regimen. Rheumatology. 2012;51:476-81.

42.• Condon MB, Ashby D, Pepper RJ, Cook HT, Levy JB, Griffith $\mathrm{M}$, et al. Prospective observational single-centre cohort study to evaluate the effectiveness of treating lupus nephritis with rituximab and mycophenolate mofetil but no oral steroids. Ann Rheum Dis. 2013;72:1280-6.

This study shows that lupus nephritis can be treated with successfully in the absence of oral steroids.

43. Lightstone L. Minimising steroids in lupus nephritis-will B cell depletion pave the way? Lupus. 2013;22:390-9.

44. Tedeschi B, Arnaud L, Hie M, et al. Successful treatment of combined proliferative and membranous lupus nephritis using a full corticosteroid-free regimen. Ann Rheum Dis. 2014;73:474-5.

45. Renal Disease Subcommittee of the American College of Rheumatology Ad Hoc Committee on Systemic Lupus Erythematosus Response Criteria. The American College of Rheumatology criteria for proliferative and membranous renal disease in systemic lupus erythematosus clinical trials. Arthritis Rheum. 2006;54:42132.

46. Petri M, Kasitanon N, Lee SS, Link K, Magder L, Bae SC, et al. Systemic lupus international collaborating clinics renal activity/response exercise: development of a renal activity score and renal response index. Arthritis Rheum. 2008;58:1784-8.

47. Gordon C, Jayne D, Pusey C, et al. European consensus statement on the terminology used in the management of lupus glomerulonephritis. Lupus. 2009;18:257-63.

48. Turner-Stokes T, Lu TY, Ehrenstein MR, Giles I, Rahman A, Isenberg DA. The efficacy of repeated treatment with B-cell depletion therapy in systemic lupus erythematosus: an evaluation. Rheumatology. 2011;50:1401-8.

49. Jónsdóttir T, Gunnarsson I, Moura AF, Lu TY, van Vollenhoven RF, Isenberg DA. Clinical improvements in proliferative vs membranous lupus nephritis following B cell depletion: pooled data from two cohorts. Rheumatology. 2010;49:1502-4.

50. Cambridge G, Leandro MJ, Teodorescu M, Manson J, Rahman A, Isenberg DA, et al. B cell depletion therapy in systemic lupus erythematosus. Effect on autoantibody and antimicrobial antibody profiles. Arthritis Rheum. 2006;54(11):3612-22.

51. Cambridge G, Isenberg DA, Edwards JC, Leandro MJ, Migone TS, Teodorescu M, et al. B cell depletion therapy in systemic lupus erythaematosus: relationships among serum B lymphocyte stimulator levels, autoantibody profile and clinical response. Ann Rheum Dis. 2008;67(7):1011-6. 